\title{
Age of the Laschamp excursion determined by U-Th dating of a speleothem geomagnetic record from North America
}

\author{
Ioan Lascu, ${ }^{1,2,3^{*}}$, Joshua M. Feinberg ${ }^{1,2}$, Jeffrey A. Dorale ${ }^{4}$, Hai Cheng ${ }^{2,5}$, and R. Lawrence Edwards ${ }^{2}$ \\ ${ }^{1}$ Institute for Rock Magnetism, University of Minnesota, 100 Union Street SE, Minneapolis, Minnesota 55455, USA \\ ${ }^{2}$ Department of Earth Sciences, University of Minnesota, 310 Pillsbury Drive SE, Minneapolis, Minnesota 55455, USA \\ ${ }^{3}$ Department of Earth Sciences, University of Cambridge, Downing Street, Cambridge, CB2 3EQ, UK \\ ${ }^{4}$ Department of Earth and Environmental Sciences, University of lowa, 115 Trowbridge Hall, lowa City, lowa 52242, USA \\ 5Institute of Global Environmental Change, Xi'an Jiaotong University, Xi'an 710049, China
}

\begin{abstract}
The Laschamp geomagnetic excursion was the first short-lived polarity event recognized and described in the paleomagnetic record, and to date remains the most studied geomagnetic event of its kind. In addition to its geophysical significance, the Laschamp is an important global geochronologic marker. The Laschamp excursion occurred around the time of the demise of Homo neanderthalensis, in conjunction with high-amplitude, rapid climatic oscillations leading into the Last Glacial Maximum, and coeval with a major supervolcano eruption in the Mediterranean. Thus, precise determination of the timing and duration of the Laschamp excursion would help in elucidating major scientific questions situated at the intersection of geology, paleoclimatology, and anthropology. Here we present a North American speleothem geomagnetic record of the Laschamp excursion that is directly dated using a combination of high-precision ${ }^{230} \mathrm{Th}$ dates and annual layer counting using confocal microscopy. We have determined a maximum excursion duration that spans the interval 42.25-39.70 ka B.P., and an age of $41.10 \pm 0.35 \mathrm{ka}$ B.P. for the main phase of the excursion, during which the virtual geomagnetic pole was situated at the southernmost latitude in the record. Our chronology provides the first age bracketing of the Laschamp excursion using radioisotopic dating, and improves on previous age determinations based on ${ }^{40} \mathrm{Ar} /{ }^{39} \mathrm{Ar}$ dating of lava flows, and orbitally tuned sedimentary and ice-core records.
\end{abstract}

\section{INTRODUCTION}

One of the frontiers of paleomagnetic research is focused on the understanding of Earth's magnetic field behavior during geomagnetic excursions. Excursions are shortlived geomagnetic events during which the virtual geomagnetic pole (VGP) deviates by more than $45^{\circ}$ from the normal range of secular variation (Merrill and McFadden, 1994), typically accompanied by a decrease in the strength of the geodynamo dipolar field component (Laj and Channell, 2007). Information regarding the anatomy, timing, and duration of excursions can serve to calibrate magnetohydrodynamic modeling of outer core flow dynamics on centennial to millennial scales, thus helping us to understand the intrinsic behavior of Earth's dynamo (Gubbins, 1999). In addition, accurate and precise high-resolution time series of geomagnetic excursions are critical for dating geologic phenomena, climatic episodes, astronomical events, or paleontologic and anthropologic stratigraphic markers (Leonhardt et al., 2009; Richards and Andersen, 2013; Singer, 2014).

The Laschamp excursion is the first geomagnetic excursion described in the paleomagnetic record, and remains the most studied geomagnetic event of its kind to date (Laj and Chan-

*E-mail: i1261@cam.ac.uk nell, 2007, and references therein). Current estimates of the age of the Laschamp, based on radioisotopic dating of volcanic rocks, place the excursion at ca. $41 \mathrm{ka} \mathrm{B.P.} \mathrm{(present} \mathrm{is} \mathrm{1950)}$ $(40.70 \pm 0.95 \mathrm{ka}$ B.P. according to Singer et al., $2009 ; 41.30 \pm 0.60 \mathrm{ka}$ B.P. according to Laj et al., 2014). In parallel, developments in sediment geochronology and paleomagnetism have enabled the reconstruction of past field behavior during the Laschamp at very high resolution in sediment cores, placing constraints on the total extent of the excursion to $<3 \mathrm{ka}$ (e.g., Lund et al., 2005; Muscheler et al., 2005; Channell, 2006; Laj et al., 2006; Ménabréaz et al., 2011), and on its main phase to $<1 \mathrm{ka}$ (e.g., Channell, 2006; Laj et al., 2006, 2014; Channell et al., 2012; Nowaczyk et al., 2012; Bourne et al., 2013). However, the timing of the Laschamp cannot be directly determined from the same sediment records in most cases. This pitfall often leads to tuning of geochemical proxies in the sedimentary records to those in ice core records, which in turn are tuned to astronomically paced changes in Earth's orbital parameters - the socalled astrochronologic framework (Laj and Channell, 2007; Nowaczyk et al., 2012). This approach has some major caveats (discussed by Blaauw, 2012).

Speleothems (chemical sedimentary deposits formed in caves) have certain key advantages for documenting geomagnetic excursions over traditional paleomagnetic archives (Lascu and Feinberg, 2011). They are crystalline, and therefore the issues associated with remanence acquisition in soft sediments are avoided. The time lag between the deposition of magnetic particles on speleothem surfaces and their encapsulation in the crystalline structure is short, as demonstrated by actively growing stalagmites that record the magnetic direction of the ambient magnetic field (e.g., Latham et al., 1979; Morinaga et al., 1989). Speleothems may grow continuously for thousands of years, and can be dated with very high accuracy and precision using ${ }^{230} \mathrm{Th}$ dating, a technique that can be reliably used on specimens younger than 700-600 ka (Edwards et al., 2003; Dorale et al., 2004; Cheng et al., 2013). Recent speleothem magnetism studies have shown that magnetic minerals encapsulated in stalagmites (e.g., Strauss et al., 2013; Font et al., 2014) can be used successfully in dating geomagnetic excursions (Osete et al., 2012), as well as for reconstructing hydrologic and climatic variations (Xie et al., 2013; Bourne et al., 2015). Here we present a speleothem geomagnetic record from Crevice Cave, Missouri, USA (Dorale et al., 1998) that captures the changes in geomagnetic field direction and intensity associated with the Laschamp excursion, dated directly on speleothem calcite using a combination of high-precision ${ }^{230} \mathrm{Th}$ dating and incremental chronometry from annual growth laminae.

\section{METHODS}

Crevice Cave $\left(37.75^{\circ} \mathrm{N}, 89.83^{\circ} \mathrm{W}\right)$ is Missouri's longest known cave, $>45 \mathrm{~km}$ in length, and is situated close to the mid-continent tallgrass prairie-deciduous forest ecotone, $\sim 200$ $\mathrm{km}$ from the southern maximum extent of the Laurentide ice sheet (Dorale et al., 1998). The studied speleothem was found in a naturally broken state in a stream-level passage of the cave. Two parallel slabs, $\sim 19 \mathrm{~cm}$ in length, were cut along the central axis of the speleothem, where growth laminae were horizontal. One of the slabs was sliced into $\sim 0.5 \mathrm{~cm}$ specimens using a wire saw, and used for paleomagnetic and mineral magnetic analyses at the Institute for Rock Magnetism (University of Minnesota, USA). Details of the experimental protocols 


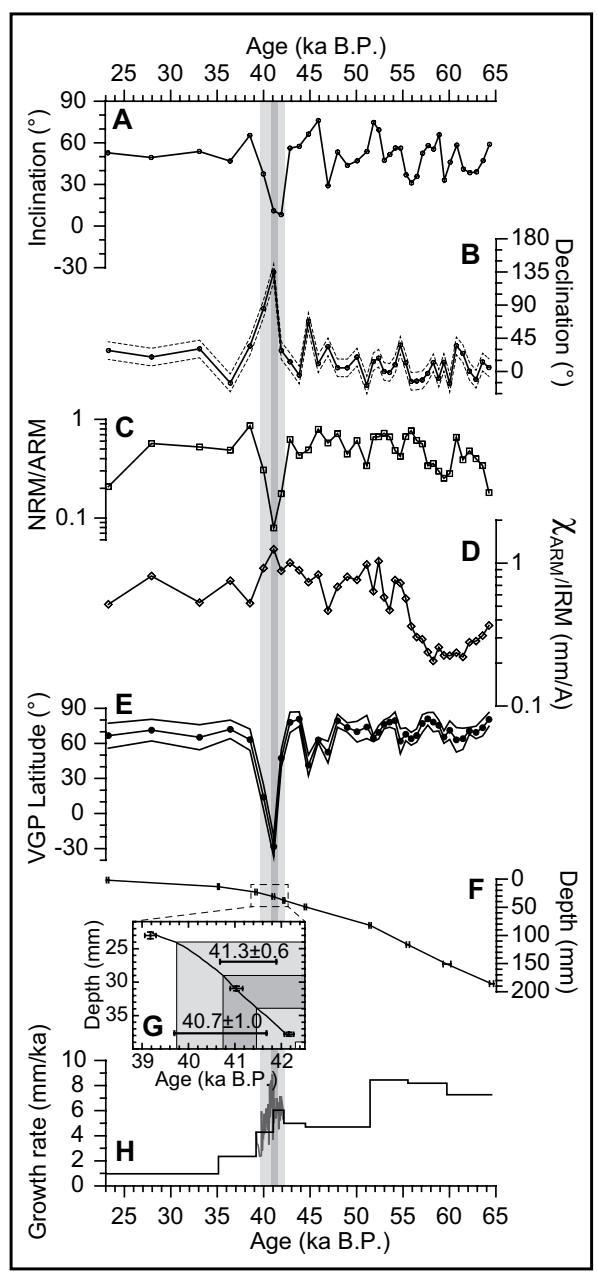

Figure 1. Magnetic properties and chronology of the Laschamp excursion in the speleothem specimen studied from Crevice Cave, Missouri (USA). A: Inclination. B: Declination. C: Relative paleointensity (NRM/ARM, natural remanent magnetization/anhysteretic remanent magnetization). D: Magnetic grain size $\left(\chi_{\mathrm{ARM}} / \mathrm{IRM}\right)$; IRM-isothermal remanent magnetization. E: Virtual geomagnetic pole (VGP) latitude. F: Age-depth model based on ${ }^{230}$ Th dates. G: Incremental chronology (from confocal microscopy layer counting) across the Laschamp, anchored to radioisotopic dates. H: Speleothem growth rates from the radioisotopic (black) and incremental (gray) age models. Upper and lower limits for declination (dashed lines in B) were calculated by rotating the specimen from $-10^{\circ}$ (lower limit) to $30^{\circ}$ (upper limit). VGP latitude uncertainty (interval delineated by continuous lines in E) was calculated via rotating the specimen through a $40^{\circ}$ declination range (see the Data Repository [see footnote 1]). The Laschamp excursion is defined by the three specimens with notable departures in inclination, declination, and relative intensity from background values (shades of gray; the main phase of the Laschamp is represented with a darker gray). A close-up of the three specimens (G) shows their individual thickness and time period covered. Previous age determinations of $40.7 \pm 1.0 \mathrm{ka}$ B.P. (Singer et al., 2009) and $41.3 \pm 0.6 \mathrm{ka}$ B.P. (Laj et al., 2014) are shown for comparison. can be found in the GSA Data Repository ${ }^{1}$. The other slab was used for constructing the age model. A Nikon A1R confocal microscope was used on the top $5 \mathrm{~cm}$ of the slab to image growth bands (Fig. DR1 in the Data Repository), based on the property of fluorescence of organic-rich layers when exposed to source light with wavelengths of $400-500 \mathrm{~nm}$. Subsequently, calcite powders were collected for ${ }^{234} \mathrm{U}-{ }^{230} \mathrm{Th}$ dating from 10 horizons, each between 0.6 and $1 \mathrm{~mm}$ in thickness, by drilling with a dental burr parallel to the growth laminae. The locations of the third and fifth dating horizons from the top were chosen to bracket the Laschamp excursion as determined from the paleomagnetic measurements. The fourth dating horizon was chosen to correspond to the paleomagnetic specimen encompassing the maximum VGP latitude deviation. Uranium and thorium isotope ratios were measured on a Thermo Neptune multicollector-inductively coupled plasma-mass spectrometer at the University of Minnesota, following the methodology of Cheng et al. (2013). An incremental chronology was obtained by counting the annual layers from the confocal micrographs between the base of the fifth and top of the third dating horizons.

\section{RESULTS}

\section{Chronology}

The radioisotopic ages are all in stratigraphic order and are reported with $2 \sigma$ uncertainties (Fig. 1; Table DR1). The speleothem started forming during marine isotope stage 4 and stopped growing just prior to the Last Glacial Maximum (LGM). Growth rates decreased 7-8 $\mathrm{mm} / \mathrm{ka}$ during the first part of the record to $\sim 5$ $\mathrm{mm} / \mathrm{ka}$ around the time of the Laschamp, eventually reaching very low values $(\sim 1 \mathrm{~mm} / \mathrm{ka})$ in the final $\sim 10 \mathrm{ka}$ of the record (Fig. 1H). The agedepth curve was obtained by interpolating linearly between the ${ }^{230} \mathrm{Th}$ dates (Fig. 1F), except between $42.17 \pm 0.10$ and $39.18 \pm 0.12$ ka B.P., where the incremental chronology (Fig. 1G), anchored to the base of the fifth dating horizon, was used. We counted $2975 \pm 20$ laminae; this is in excellent agreement with the radioisotopic age difference of 2988 (with $2 \sigma$ errors of $\sim \pm 100$ $y r)$, confirming the annual nature of the calcite growth bands. The depth-age relationship is linear between the ${ }^{230} \mathrm{Th}$ dates of $42.17 \pm 0.10$ and $41.03 \pm 0.13 \mathrm{ka}$ B.P., but deviates slightly

${ }^{1}$ GSA Data Repository item 2016036, magnetic methods, Tables DR1-DR3 (radioisotopic dating results, magnetic time series, incremental chronology), and Figures DR1 and DR2 (confocal micrograph, Zijderveld plot of strongly magnetic specimen), is available online at www.geosociety.org/pubs/ft2016 .htm, or on request from editing@ geosociety.org or Documents Secretary, GSA, P.O. Box 9140, Boulder, CO 80301, USA. from this trend between $41.03 \pm 0.13$ and 39.18 \pm 0.12 ka B.P., as growth slowed approaching the LGM.

\section{Rock Magnetism and Paleomagnetism}

The main magnetic carrier in our specimens is magnetite, as revealed by low-temperature experiments (Fig. 2B). The ratio of anhysteretic remanent magnetization (ARM) susceptibility $\left(\chi_{\mathrm{ARM}}\right)$ to isothermal remanent magnetization (IRM), or $\chi_{\text {ARM }}$ /IRM, a grain-size indicator, is $<0.4 \mathrm{~mm} / \mathrm{A}$ for specimens older than $\sim 55 \mathrm{ka}$, and $>0.4 \mathrm{~mm} / \mathrm{A}$ for younger specimens (Fig. 1D). At ca. $41 \mathrm{ka}$ B.P., $\chi_{\mathrm{ARM}} / \mathrm{IRM}$ is $\sim 1 \mathrm{~mm} / \mathrm{A}$, a value typical for pedogenic single domain magnetite particles a few tens of nanometers in size (Geiss et al., 2008). Lower values indicate a more important admixture of coarser, lithogenic magnetic grains.

Paleomagnetic directions exhibit a significant deviation from normal secular variation values between ca. 42 and 39 ka B.P., an event we associate with the Laschamp excursion (Figs. $1 \mathrm{~A}-1 \mathrm{C}, 1 \mathrm{E})$. Inclination values decrease to $\sim 10^{\circ}$ shortly after $42 \mathrm{ka}$ B.P. (Fig. 1A), and the main declination swing occurs ca. 41 ka B.P. (Fig. 1B), lagging the first inclination change by $\sim 1$ $\mathrm{ka}$. The ratio of natural remanent magnetization (NRM) to ARM, a relative paleointensity proxy, is lowest at ca. $41 \mathrm{ka}$ (Fig. 1C), concomitant with the maximum directional excursion. The decrease in NRM/ARM is a change of one order of magnitude compared to average background values, and is not due to a magnetic grain size change, as $\chi_{\mathrm{ARM}} / \mathrm{IRM}$ remains fairly constant (Figs. 1D and 2A). The VGP is in the Southern Hemisphere at this time ( - $30^{\circ}$; Fig. 1E).

The alternating field (AF) demagnetization experiments generally show a (quasi-) linear decay of the NRM toward the origin (Figs. 2C and 2D; Fig. DR2), even for specimens with lower magnetic concentrations (NRM $<10^{-7} \mathrm{Am}^{2} /$ $\mathrm{kg}$ ). Viscous overprints are removed at $2-5 \mathrm{mT}$ peak AF demagnetization fields (Figs. 2C-2E). Based on the demagnetization behavior of most of the specimens, we attribute clustering demagnetization patterns (e.g., Fig. 2E) to low intensity levels ( $\mathrm{NRM}<10^{-8} \mathrm{Am}^{2} / \mathrm{kg}$ ), rather than to erratic demagnetization behavior.

\section{DISCUSSION}

\section{Timing and Duration of the Laschamp Excursion}

Radioisotopic dating of volcanic rocks, mainly using the ${ }^{40} \mathrm{Ar} /{ }^{39} \mathrm{Ar}$ method, is the current state of the art approach to determining the timing of late Quaternary geomagnetic events (Singer, 2014). Recent Laschamp age determinations were reported by Singer et al. (2009) and Laj et al. (2014), who placed the excursion at $40.70 \pm 0.95 \mathrm{ka} \mathrm{B} . P$. and $41.30 \pm 0.60 \mathrm{ka} \mathrm{B.P.}$, respectively. These age estimates, however, 
Figure 2. A: Comparison of natural remanent magnetization (NRM), anhysteretic remanent magnetization (ARM), and isothermal remanent magnetization (IRM) time series. Note the deviation of NRM values from trends exhibited by ARM and IRM between 42 and 39 ka B.P. B: Low-temperature saturation IRM (LT-SIRM) behavior on warming after field-cooled (FC) and zero field-cooled (ZFC) pretreatments, and room-temperature saturation IRM (RT-SIRM) behavior on successive warming (black triangles) and cooling (open triangles) cycles, showing the presence of oxidized magnetite. M-magnetization. C-E: Orthogonal projections and azimuthal equidistant plots of specimens defining the Laschamp excursion (labeled on the NRM curve in A). Full squares represent the horizontal projections of the demagnetization vectors (gray arrows); open squares represent the vertical projections. Gray symbols are viscous overprints removed by alternating field (AF) peak fields of $5 \mathrm{mT}$. Unit in orthogonal plots is $5 \times 10^{-12} \mathrm{Am}^{2}$. Magnetometer noise level is $\sim 10^{-11} \mathrm{Am}^{2}$.

were determined by pooling data sets from various flows that yield individual ages with errors $>1 \mathrm{ka}$ in all cases. The ${ }^{234} \mathrm{U} /{ }^{230} \mathrm{Th}$ method applied to speleothems has the potential of providing individual errors at least an order of magnitude smaller for calcite precipitated at ca. 40 ka B.P. (Cheng et al., 2013). The Crevice Cave specimen, albeit slow growing, has high concentrations of uranium (Table DR1); this allows for ${ }^{230} \mathrm{Th}$ dates to be determined with errors of $\sim 100 \mathrm{yr}$ for calcite horizons $<1 \mathrm{~mm}$ in thickness. Our paleomagnetic specimens are 4-5 mm thick, so after factoring in the sampling resolution, we find that the main phase of the Laschamp excursion in our speleothem occurred $41.10 \pm 0.35$ ka B.P., as determined from the specimen that contains the maximum VGP deviation (Fig. 1). This refines the precision of the excursion timing compared to the age estimates proposed by Singer et al. (2009) and Laj et al. (2014), with improved error estimates by a factor of $2-3$. The uncertainty of the timing of the Laschamp excursion could be further refined using this approach by targeting speleothems with higher growth rates.

Although lava flows provide excellent spot records of geomagnetic excursions, the current dating precision of the ${ }^{40} \mathrm{Ar} /{ }^{39} \mathrm{Ar}$ method is several thousands of years, precluding any meaningful attempt to robustly bracket the duration of such short-lived events. The two ${ }^{230} \mathrm{Th}$ dates bracketing the Laschamp excursion in the Crevice Cave speleothem serve as anchors to an incremental age model that allows the calculation of the time interval covered by the speleothem specimens that contain the field directional swing and intensity low that define the excursion. According to our speleothem record, the entire excursion spans the time interval from 42.25 to 39.70 ka B.P., a duration of $\sim 2550 \mathrm{yr}$. The main phase of the Laschamp is defined by one speleothem specimen, which encompasses $\sim 700 \mathrm{yr}$ for which the field direction was of reverse polarity (average VGP latitude of $\sim-30^{\circ}$ ). These are maximum values, and are consistent with excursion durations determined from sedimentary records around the globe. One of the best records of the Laschamp excursion comes from the Black Sea, where the entire period of directional variations was estimated to be just $<3 \mathrm{ka}$, with transitional or reverse directions (and associated paleointensity low) lasting $\sim 1.6 \mathrm{ka}$, out of which fully reverse directions were maintained for $440 \mathrm{yr}$ (Nowaczyk et al., 2012). Similarly, a short full reversal of 0.4-0.8 ka, superimposed on a background of low relative paleointensity that lasted $1.5-2$ $\mathrm{ka}$, is reported from cores from the Blake Ridge (Bourne et al., 2013), the Bermuda Rise (Kissel et al., 1999; Channell et al., 2012), Irminger Basin (Channell, 2006), northwest of Iceland, and the southern Indian Ocean (Laj et al., 2006). These paleomagnetic data are consistent with cosmogenic nuclide production rates from sediment and ice cores (e.g., Muscheler et al., 2005; Ménabréaz et al., 2011; Nilsson et al., 2011), and are supported by Bayesian inversion of geomagnetic field evolution during the Laschamp in
North America (Leonhardt et al., 2009). Bayesian inversion also suggests that the timing and duration of the Laschamp may vary according to locality (Leonhardt et al., 2009). Precise dating of additional speleothem geomagnetic records of the Laschamp from key locations around the globe would provide the means for testing this inferred asynchroneity.

\section{Potential of Speleothems in Dating Brunhes Age Excursions}

Geomagnetic excursions are reflections of geodynamo dynamics on short time scales. A rigorous documentation of the anatomy, timing, duration, and/or frequency of such short-lived events can be invaluable for theoretical and numerical geodynamo models. Well-constrained age models are critical for characterizing geomagnetic instabilities, and are key in developing high-resolution geomagnetic time series. One such effort is the development of the Quaternary geomagnetic instability time scale. Within this framework, Singer (2014) synthesized the current understanding of excursional occurrence within the Brunhes chron. Geomagnetic excursions appear to be concentrated within two 200 ka time periods (722-528 and 211-17 ka B.P.), each containing 6-7 excursions, that are in the dating range of the ${ }^{234} \mathrm{U} /{ }^{230} \mathrm{Th}$ method (Edwards et al., 2003; Dorale et al., 2004; Cheng et al., 2013). The younger Brunhes excursions would particularly benefit from precise pinpointing by taking advantage of this method, which under ideal circumstances yields $2 \sigma$ uncertainties as low as $\pm 0.1 \mathrm{ka}$ at $130 \mathrm{ka}$ B.P., and $\pm 0.3 \mathrm{ka}$ at $200 \mathrm{ka} \mathrm{B.P.} \mathrm{(Cheng} \mathrm{et} \mathrm{al.,} \mathrm{2013).} \mathrm{The} \mathrm{older}$ Brunhes excursions, although pushing the limit of the ${ }^{230} \mathrm{Th}$ dating method ( $2 \sigma$ uncertainties of $\pm 6 \mathrm{ka}$ at $500 \mathrm{ka} \mathrm{B.P.} \mathrm{and} \pm 12 \mathrm{ka}$ at $600 \mathrm{ka}$ B.P.), could also benefit from this approach, especially if it is possible to combine radioisotopic and incremental dating methods. A good example of dating a speleothem that formed between 640 and 510 ka B.P. was provided by Cheng et al. (2013), demonstrating the viability of the ${ }^{234} \mathrm{U}^{230} \mathrm{Th}$ method.

\section{ACKNOWLEDGMENTS}

This project was funded by National Science Foundation grant EAR-1316385, a University of Minnesota McKnight Land Grant Professorship to Feinberg, and European Research Council grant 320750. Confocal microscopy was performed at the University of Minnesota Imaging Centers. We are grateful to John Geissman, Brad Singer, and James Channell for their constructive reviews. This is Institute for Rock Magnetism (University of Minnesota) contribution 1506.

\section{REFERENCES CITED}

Blaauw, M., 2012, Out of tune: The dangers of aligning proxy archives: Quaternary Science Reviews, v. 36 , p. 38-49, doi:10.1016/j.quascirev 2010.11.012.

Bourne, M.D., Mac Niocaill, C., Thomas, A.L., and Henderson, G.M., 2013, High-resolution record of the Laschamp geomagnetic excursion at the 
Blake-Bahama Outer Ridge: Geophysical Journal International, v. 195 , p. $1519-1533$, doi: 10.1093/gji/ggt327.

Bourne, M.D., Feinberg, J.M., Strauss, B.E., Hardt, B., Cheng, H., Rowe, H.D., Springer, G., and Edwards, R.L., 2015, Long-term changes in precipitation recorded by magnetic minerals in speleothems: Geology, v. 43, p. 595-598, doi: 10.1130/G36695.1.

Channell, J., 2006, Late Brunhes polarity excursions (Mono Lake, Laschamp, Iceland Basin and Pringle Falls) recorded at ODP Site 919 (Irminger Basin): Earth and Planetary Science Letters, v. 244, p. 378-393, doi:10.1016/j.epsl.2006.01.021.

Channell, J.E.T., Hodell, D.A., and Curtis, J.H., 2012, ODP Site 1063 (Bermuda Rise) revisited: Oxygen isotopes, excursions and paleointensity in the Brunhes Chron: Geochemistry, Geophysics, Geosystems, v. 13, Q02001, doi:10.1029 /2011GC003897.

Cheng, H., et al., 2013, Improvements in ${ }^{230} \mathrm{Th}$ dating, ${ }^{230} \mathrm{Th}$ and ${ }^{234} \mathrm{U}$ half-life values, and U-Th isotopic measurements by multi-collector inductively coupled plasma mass spectrometry: Earth and Planetary Science Letters, v. 371372, p. 82-91, doi:10.1016/j.epsl.2013.04.006.

Dorale, J.A., Edwards, R.L., Ito, E., and González, L.A., 1998, Climate and vegetation history of the midcontinent from 75 to $25 \mathrm{ka}$ : A speleothem record from Crevice Cave, Missouri, USA: Science, v. 282, p. 1871-1874, doi:10.1126/science .282 .5395 .1871

Dorale, J.A., Edwards, R.L., Alexander, E.C., Shen, C., Richards, D.A., and Cheng, H., 2004, Uranium-series dating of speleothems: Current techniques, limits, \& applications, in Sasowsky, I.D., and Mylroie, J.E., eds., Studies of cave sediments: Physical and chemical records of paleoclimate: Amsterdam, Springer, p. 177-197, doi:10.1007/978-1-4419-9118-8_10.

Edwards, R.L., Gallup, C.D., and Cheng, H., 2003 , Uranium-series dating of marine and lacustrine carbonates, in Bourdon, B., et al., eds., Uraniumseries geochemistry: Mineralogical Society of America Reviews in Mineralogy and Geochemistry Volume 52, p. 363-405, doi:10.2113/0520363.

Font, E., Veiga-Pires, C., Pozo, M., Carvallo, C., de Siqueira Neto, A.C., Camps, P., Fabre, S., and Mirão, J., 2014, Magnetic fingerprint of southern Portuguese speleothems and implications for paleomagnetism and environmental magnetism: Journal of Geophysical Research, v. 119, p. 1-28, doi:10.1002/2014JB011381.

Geiss, C.E., Egli, R., and Zanner, C.W., 2008, Direct estimates of pedogenic magnetite as a tool to reconstruct past climates from buried soils: Journal of Geophysical Research, v. 113, B11102, doi:10.1029/2008JB005669.

Gubbins, D., 1999, The distinction between geomagnetic excursions and reversals: Geophysi- cal Journal International, v. 137, p. F1-F4, doi: 10.1046/j.1365-246x.1999.00810.x.

Kissel, C., Laj, C., Labeyrie, L., Dokken, T., Voelker, A., and Blamart, D., 1999, Rapid climatic variations during marine isotopic stage 3: Magnetic analysis of sediments from Nordic Seas and North Atlantic: Earth and Planetary Science Letters, v. 171, p. 489-502, doi:10.1016/S0012 $-821 X(99) 00162-4$

Laj, C., and Channell, J.E.T., 2007, Geomagnetic excursions, in Kono, M., ed., Geomagnetism: Treatise on Geophysics Volume 5: Amsterdam, Elsevier, p. 373-416.

Laj, C., Kissel, C., and Roberts, A.P., 2006, Geomagnetic field behavior during the Iceland Basin and Laschamp geomagnetic excursions: A simple transitional field geometry?: Geochemistry, Geophysics, Geosystems, v. 7, Q03004, doi: 10.1029/2005GC001122.

Laj, C., Guillou, H., and Kissel, C., 2014, Dynamics of the Earth magnetic field in the $10-75 \mathrm{kyr}$ period comprising the Laschamp and Mono Lake excursions: New results from the French Chaîne des Puys in a global perspective: Earth and Planetary Science Letters, v. 387, p. 184-197, doi: 10.1016/j.epsl.2013.11.031.

Lascu, I., and Feinberg, J.M., 2011, Speleothem magnetism: Quaternary Science Reviews, v. 30, p. 33063320, doi:10.1016/j.quascirev.2011.08.004

Latham, A.G., Schwarz, H.P., Ford, D.C., and Pearce, G.W., 1979, Palaeomagnetism of stalagmite deposits: Nature, v. 280 , p. 383-385, doi: 10.1038/280383a0.

Leonhardt, R., Fabian, K., Winklhofer, M., Ferk, A., Laj, C., and Kissel, C., 2009, Geomagnetic field evolution during the Laschamp excursion: Earth and Planetary Science Letters, v. 278, p. 87-95, doi:10.1016/j.epsl.2008.11.028.

Lund, S.P., Schwartz, M., Keigwin, L., and Johnson, T., 2005, Deep-sea sediment records of the Laschamp geomagnetic field excursion $(\sim 41,000$ calendar years before present): Journal of Geophysical Research, v. 110, B04101, doi:10.1029 /2003JB002943.

Ménabréaz, L., Thouveny, N., Bourlès, D.L., Deschamps, P., Hamelin, B., and Demory, F., 2011, The Laschamp geomagnetic dipole low expressed as a cosmogenic ${ }^{10} \mathrm{Be}$ atmospheric overproduction at $\sim 41 \mathrm{ka}$ : Earth and Planetary Science Letters, v. 312, p. 305-317, doi:10.1016/j .epsl.2011.10.037.

Merrill, R.T., and McFadden, P.L., 1994, Geomagnetic field stability: Reversal events and excursions: Earth and Planetary Science Letters, v. 121 , p. $57-69$, doi:10.1016/0012-821X(94) 90031-0.

Morinaga, H., Inokuchi, H., and Yaskawa, K., 1989, Palaeomagnetism of stalagmites (speleothems) in SW Japan: Geophysical Journal, v. 96, p. 519528, doi:10.1111/j.1365-246X.1989.tb06011.x.
Muscheler, R., Beer, J., Kubik, P.W., and Synal, H.A., 2005, Geomagnetic field intensity during the last 60,000 years based on ${ }^{10} \mathrm{Be}$ and ${ }^{36} \mathrm{Cl}$ from the Summit ice cores and ${ }^{14} \mathrm{C}$ : Quaternary Science Reviews, v. 24, p. 1849-1860, doi:10.1016/j .quascirev.2005.01.012.

Nilsson, A., Muscheler, R., Snowball, I., Aldahan, A., Possnert, G., Augustinus, P., Atkin, D., and Stephens, T., 2011, Multi-proxy identification of the Laschamp geomagnetic field excursion in Lake Pupuke, New Zealand: Earth and Planetary Science Letters, v. 311, p. 155-164, doi: 10.1016/j.epsl.2011.08.050

Nowaczyk, N.R., Arz, H.W., Frank, U., Kind, J., and Plessen, B., 2012, Dynamics of the Laschamp geomagnetic excursion from Black Sea sediments: Earth and Planetary Science Letters, v. $351-352$, p. $54-69$, doi:10.1016/j.epsl.2012 .06 .050 .

Osete, M.-L., Martín-Chivelet, J., Rossi, C., Edwards, R.L., Egli, R., Muñoz-García, M.B., Wang, X., Pavón-Carrasco, F.J., and Heller, F., 2012, The Blake geomagnetic excursion recorded in a radiometrically dated speleothem: Earth and Planetary Science Letters, v. 353-354, p. 173-181, doi:10.1016/j.epsl.2012.07.041.

Richards, D.A., and Andersen, M.B., 2013, Time constraints and tie-points in the Quaternary Period: Elements, v. 9, p. 45-51, doi:10.2113 /gselements.9.1.45.

Singer, B.S., 2014, A Quaternary geomagnetic instability time scale: Quaternary Geochronology, v. 21, p. 29-52, doi:10.1016/j.quageo.2013 .10 .003 .

Singer, B.S., Guillou, H., Jicha, B.R., Laj, C., Kissel, C., Beard, B.L., and Johnson, C.M., 2009, ${ }^{40} \mathrm{Ar} /{ }^{39} \mathrm{Ar}$, K-Ar and ${ }^{230} \mathrm{Th}^{238} \mathrm{U}$ dating of the Laschamp excursion: A radioisotopic tie-point for ice core and climate chronologies: Earth and Planetary Science Letters, v. 286, p. 80-88, doi: 10.1016/j.epsl.2009.06.030.

Strauss, B.E., Strehlau, J.H., Lascu, I., Dorale, J.A., Penn, R.L., and Feinberg, J.M., 2013, The origin of magnetic remanence in stalagmites: Observations from electron microscopy and rock magnetism: Geochemistry, Geophysics, Geosystems, v. 14 , p. $5006-5025$, doi:10.1002 /2013GC004950.

Xie, S., et al., 2013, Concordant monsoon-driven postglacial hydrological changes in peat and stalagmite records and their impacts on prehistoric cultures in central China: Geology, v. 41, p. 827-830, doi:10.1130/G34318.1.

Manuscript received 7 November 2015

Revised manuscript received 8 December 2015

Manuscript accepted 10 December 2015

Printed in USA 